\title{
Retrospective Analysis of Social and Cultural Meanings of Motherhood in Russia
}

\author{
Nataliya N. Vasyagina ${ }^{1} \&$ Aidar M. Kalimullin ${ }^{2}$ \\ ${ }^{1}$ Ural State Pedagogical University, Yekaterinburg, Russia \\ ${ }^{2}$ Kazan (Volga region) Federal University, Kazan, Russia \\ Correspondence: Nataliya Nicolaevna Vasyagina, Ural State Pedagogical University, Cosmonauts avenue 32, \\ Yekaterinburg, 620017, Russia. E-mail: vasyagina_n@mail.ru
}

\author{
Received: January 19, $2014 \quad$ Accepted: February 22, $2015 \quad$ Online Published: March 25, 2015 \\ doi:10.5539/res.v7n5p61 \\ URL: http://dx.doi.org/10.5539/res.v7n5p61
}

\begin{abstract}
The world of today, and Russia in particular, encounters the transformation of maternity: its essence and status of a universal value are being lost. Therefore, the basic aim of the article is to go back to roots by discovering theoretical basis for sociocultural essence of maternity in different periods of Russian social history in order to understand the reasons of these changes, reveal the present status of maternity and its meaning in modern Russia. The research is based upon cultural-historic approach which is aimed to reveal sociocultural determinants of human existence. The author shows that motherhood as a social and cultural phenomenon contains the genesis of the Russian culture, its socio-historical, moral and family experience. As a measure of the Russian society civility and maturity at each stage of social development social and cultural meanings of motherhood, influencing the consciousness and behavior of its subjects, determine the depth of assimilation, acceptance or rejection of motherhood as an independent value. The materials presented in the article may be used in higher educational establishments for the realization of professionally-oriented curricula in Pedagogical Psychology and Sociocultural Studies; including in-service courses for specialists whose professional activity is closely connected with family, maternity and child maintenance.
\end{abstract}

Keywords: motherhood, Russian culture, socio-cultural meaning of motherhood, the value of motherhood, the image of the mother

\section{Introduction}

In the cultural heritage of many nations, motherhood is the highest embodiment of the feminine (Chodorow, 2008; Isupova, 2000; Ramih, 1997; Shamarina, 2008; Vasyagina, 2013a; Mokeyeva et al., 2015; Biktagirova \& Valeeva, 2015). However, in the modern world social, political, and economic transformations have led to improvements in the educational and professional level of women, increasing their role in all spheres of public life, and contributed to the emergence of such phenomena as family crisis, the devaluation of motherhood on the social and individual levels. Here comes the erosion of the socio-cultural meaning of motherhood and its purpose. Motherhood ceases to be the leading value for women. This situation indicates a crisis of traditional motherhood taking place in the modern world in general and in Russia in particular. That has generated many problems, disputes about the future of the humankind, whether it is able to survive, about its reproductive ways in the physical and social terms.

Without a doubt, the questions need to be solved immediately. It is highly important to find the answers to the motherhood problems that give us the sense of the evolution of socio-cultural patterns of meaning in context of the changes taking place in the society and family, in the social status of women, her family and other orientations at different stages of the Russian culture development. The resulting data in the course of this comparative analysis was the subject of reflection of the author of the article.

\section{Methodological Framework}

Ideas of cultural-historic approach, revealing sociocultural determinants of human existence and dependence of human psychic on the material and spiritual heritage of a society, lay the foundation for this research. The use of historiographic and hermeneutic methods was put forward by the necessity of retrospective analysis and understanding of sociocultural meanings of maternity. In order to theoretically analyze and compare various 
scientific concepts of maternity methods of comparative analysis, systematization and conceptualization were thoroughly applied.

\section{Results}

It should be noted that various cults of motherhood associating with Earth were widespread at the earliest stages of the Russian culture. Our ancestors associated Earth (that is emanation itself) with the Mother Goddess for only a woman and Earth can give a birth, and create life. The cult of Mokosh was widespread among the pagan cults of Ancient Russia. Mokosh diva is a very ancient agricultural deity, the mother of the harvest, the goddess of fertility that was associated with the rites and agrarian magic. Such cults praising mother existed in most civilizations regardless of the position and status women had.

The female deity cult determined the meaning of motherhood and socio-cultural attitudes towards women and mothers in ancient Russia. These were the goddess (Eternal Mother) of the powers of Nature, the goddess of sexual love and reproduction, and the goddess of fertility. These images established relations between all the people in general and women in particular. It is an image of a woman giving birth, protecting, loving, and caring. It is an image of the mother and wife. The cult gave the woman features of fertility, wealth, wisdom, prosperity, and kinship. The woman mysteriously is likened to the earth, and childbearing is represented as a variation on the human level fertility of the land. The sanctity of women is in direct proportion to the sanctity of Earth.

Along with the adoption of Christianity (the second half of the tenth century) Russia redefined the concept of demographic Russian ethnos. Christian standards propounded by the Russian Orthodox Church, were the source of the strengthening of common cultural values of the society, such as family, marriage, possession of many children. Being a social ideal, the value of childbearing embodied in the image of Our Lady, determined the emergence of the idea-image of women as mothers. It is the image of the Virgin and Child Jesus that mainly appears in the public consciousness of Russians. It is a cultural symbol that defines the concept of the sanctity of mothers, their value to the world). Thus, under the influence of Christianity, psychological image of the woman-mother has appeared, in which the mother attributed most Christian qualities: caring, compassion, sacrifice, asexuality, modesty, chastity, patience, compassion, love and beauty. It should be emphasized that the Christian vision of motherhood is the only Russian ideologeme existed until the end of the XIX century (Vasyagina, 2013b). Besides, it is the image of the mother established in that period passing through the scientific and religious thought of different times of the Russian people, has developed into a kind of universal archetype of motherhood.

At the turn of the XIX-XX centuries, two opposite directions were formed in Russia. The first one suggested solving the motherhood problems by the means of philosopho-religious analysis, whereas the second one was conducted through the measures of Marxist-Enlightenment analysis.

Within the context of Russian religious philosophy, "mother" is defined as "the heart of the Russian religiosity". "Mother giving birth, shining in the faith and love is the very heart of life processes, the foundation of life". "The mother carries the meaning of holiness and heroism as the highest spiritual values of the mankind". The idea of comicality of the mother is being claimed. "Mother" is not only the ancestress of some particular human beings, but rather the whole universe. The dominant feature of the mother is her spirituality, through which the mother keeps and transfers the human values (Shamarina, 2008).

Under the influence of the Marxism ideology, a completely different vision of "mother" and her role in life' started to appear in the late XIX - early XX century. "The idea of social equality between men and women was the basis for the redefining the term 'mother' from the point of view of 'mother' as a parent to 'mother' as a mere social unit". The idea stressed the need to create conditions for the implementation of equivalent women in to motherhood and other spheres of the society. Under the influence of these ideas, the process of women emancipation started taking shape in Russia, and the concept of "the new woman" (Goldman, 2002) was being formed along the way. The woman's work must be valued in terms of the society, government, workforce and its needs more rather than a simple housework and childcare. "We must spare the woman's strength from the non-productive work in the family to be able to use it more efficiently for the sake of the society... The mother who is spending her energy in caring for her children and housekeeping, will never be maximum productive (Steiner, 2005). The only duty women must have is childbearing and breast-feeding in the pre-day care facilities period. Anything else from that point must be the government's highest concern".

It should be emphasized that there were no works devoted to the motherhood problems published in the USSR at that time. Nevertheless, the Soviet period had always attracted the attention of the foreign researchers on that matter. Suffice to mention that there was a number of books devoted to the singularity of the Bolshevism movement published in both pre- and after the wars periods. Hereby one book should be distinguished in that 
relation. It is written by Wood, and is called "Woman and friend". Although the book is about political history, it still has a chapter, in which the post-revolutionary transformations of the first half of the XX century are described. The author succeeded in impartially depicting the legal documents related to the civil war and precise analysis of the works of the notable persons of the Bolshevist party, whose books were devoted to the motherhood issues and considered this women's duty as something incomparable with the revolutionary duties (Wood, 1997).

Mostly motherhood (or how it was being understood in the USSR) and so called "the women's question" (Scheide, 2002) were a subject of interest for many foreign writers. There was a legislation act of 1936 banning abortions in the USSR that got a lot of attention all over the country. The act expanded its coverage to many spheres of people's lives in that period.

During the second half of the XX century, the motherhood issues started to be solved. The Communist Party of the Soviet Union set a challenge to harmonize both the women's involvement into the working process and their motherhood. In the year of 1956, the Soviet women started to get the maternity aid. All pregnant women got a possibility on isolation from work basis to prepare for the arrival of the child. There were other privileges for the pregnant women that started to appear as well.

The new tendency appeared in the era of the "Brezhnevian Stagnation" (1964-1982): the problem of "Women in the workforce" became actual, and as the result, the list of "closed" women's professions because of health risk was established in 1970. During the same period, there were independent researches in the field of motherhood, which were united in a socio-demographic approach, within which, specific problems of women were studied as a special demographic group. The main place among the allocated problems is taken by insoluble aspiration of uniform combination of professional, public and family roles (Isupova, 2000).

Despite the outlined changes, since the end of the XIX century and throughout all the Soviet period, social activity and professional success of the female toiler are socially approved values. This social practice unambiguously put social and professional roles of the woman in the forefront. The same cannot be said about her family, maternal functions. There was a certain contradiction between the declared social status of the motherhood and real opportunities of its realization. Almost all social privileges in the USSR were provided according to the labor code and depending on labor employment of women. As V. A. Ramih fairly notes (Ramih,1997), if in the society the role of mother is appreciated below any work in a social production, the woman has to accept this idea get engaged in the activity that the society considers more important. The motherhood becomes secondary to women and the functions of motherhood lose their original socio-cultural meaning.

Current situation led to the birth rate falling in the USSR. The analysis of the reasons of the growing crisis showed a strong need of immediate reorientation of women's employment from the sphere of work to the family. Since 1983, mothers have had a legal opportunity not to come to work (child rearing leave) until the child turns 3 years old. For the short period it had improved the country's demography a little - some growth of birth rate was outlined. However, along with Collapse of the Soviet Union the situation changed for the worse again. All measures for stimulation of birth rate such as prohibition of abortions, encouragement of large families and the state support of single mothers had only short-term results: as in the Soviet socio-cultural space the value of "merciful mother" was transformed into the value of mother toiler, and throughout the Soviet period mothers were "free" from bringing up children, which inevitably led to the loss in understanding of motherhood as the supreme value of the society.

During the time of Perestroika, there were significant changes in socio-cultural space of Russia, which had essential impact on the motherhood: in 1994, the presidential program "family planning" was approved. The main direction was a health protection of women and children, proper informing of teenagers and youth about a reproductive behavior. Since 1995, another Federal target program "Safe Motherhood" has started working parallel with the "family planning" program. The organization of the centers of the family planning and reproduction, the centers of reproductive health of the youth was a result of the implementation of the programs. Despite the undertaken measures for protection of motherhood and the childhood, scientific and medical achievements, psychological problems of motherhood did not decrease.

Modern transformations in Russia did not solve old problems. They generated a set of new problems in the field of motherhood, instead. According to a number of researchers (Isupova, 2000), the situation with motherhood in modern Russia is deplorable: the modern demographic situation, valuable ambiguity of such phenomena as social issues and surrogacy are the factors signifying a crisis of ideology of the motherhood. Many problems are the causes of difficult economic and social situation in the country, instability; also, they are the result of the 
women decision to refuse the motherhood. The breach in the intergenerational relationships, the loss of traditional ways of sharing knowledge and clearance of maternal-child interaction, all these reasons lead to accentuated binarity of social and cultural meaning of motherhood in modern Russia: one point is that as losing value of the meaning of motherhood, the woman becomes an active subject in the field of social work. The other point is that for women in an unstable society, the importance of the family increases, in which the need of its members in love and security is vitally important, and the child is the guarantor of the possible and full realization in life (Vasyagina, 2010).

Roots of the first tendency go back to the Soviet period: transformation in the Soviet Russia from female mother's values into the female toiler's value, loss of understanding of motherhood as the supreme value, and also striving to achieve personal success and independence led to the fact that a significant part of contemporary Russian women perceive motherhood as a burden, an obstacle to professional development as something to what it is necessary to reconcile someday. For that kind of women the Value of motherhood is pushed aside by other values (professional or material goals, self-development, self-realization, etc.) therefore a dilemma "the child or the career" even more often is solved in favor of the career, Creation of the family is postponed for late term, the number of children in the family decreases, the deviant motherhood increases.

Opposite in content is a trend that is associated with the rebirth of the original essence of motherhood. In this context, the understanding of social and cultural meaning of motherhood presents multi-faceted, and is revealed through the prism of the two main directions.

In the first direction, motherhood is seen as a prerequisite for child development. Mother and child are considered components of a single dyadic system; the content of the parent image is caused by the style of the relationship of the mother and the child and the characteristics of parent-child interaction; great attention is paid to consideration of the styles and types of parent relations, violations of the system of family education and disharmony family relations as the major factors behind the emergence of neuroses and psychopathy of children.

The second direction considering motherhood as part of the personal sphere of women is relatively new for Russian psychology. With all variability of the conceptual positions carried to this direction, it is possible to divide them into two positions: gender and subject activity. The first of the called positions explains motherhood as one of the gender roles of the woman causing success of resolution of crisis and possibility of self-realization in formation of gender identity. The second direction considers it as a dynamic system of interactions of the subject with activity in the course of which there is an embodiment in the object of a mental image and realization of the subject's relations with the world. The image of the mother is different and the requirements for her are special: the mother here is not only the mother, but also "the teacher" of her children, their "social pedagogue", the guide to the world of socio-cultural reality, the subject of education. The mother herself is perceived as active and independent entity, and motherhood is perceived as a result of free and spiritual choice for the woman (Vasyagina, 2013a). In this sense, motherhood is not just a necessity or a tribute to social and cultural facilities but independent conscious personal choice for the woman.

\section{Discussions}

Sociocultural aspect of studying maternity has been used as a subject for analysis by both Russian and foreign scholars. The attitude of a society towards a woman-mother (Isupova, 2000), ways and mechanisms of a society's influence on reproductive behaviour (Chodorow, 2008), types of reproductive behaviuor (Glenn, 1994) were studied. The change in maternity mental sets from epoch to epoch (Badinter, 1981) was proved; the variability in mother's attitude towards her child and its dependence on historical and cultural peculiarities (Palasios, 2008) was stated, the leading role of social learning in women's behaviour (Hay \& Vespo, 1988) was claimed. In spite of these well-developed concepts, up to now there has been no theory revealing sociocultural meanings of maternity in different periods of Russian social history. However, it is this context of problem-studying that allows us, in our opinion, to understand the reasons of maternity status changes and discover its true position and essence in modern Russia.

\section{Conclusion}

Thus, the retrospective analysis of dynamics of socio-cultural meanings of motherhood in Russia presented in this article shows motherhood as a socio-cultural phenomenon and comprises the genesis of the Russian culture in general, its socio-historical, moral and family experience. As a measure of the Russian society civility and maturity at each stage of social development, social and cultural meanings of motherhood, influencing the consciousness and behavior of its subjects, determine the depth of assimilation, acceptance or rejection of motherhood as an independent value. 


\section{Recommendations}

The materials presented in the article may be used in higher educational establishments for the realization of professionally-oriented curricula in Pedagogical Psychology and Sociocultural Studies; courses in Cultural Studies, Family Psychology, Social Psychology, Personality Psychology etc., including in-service courses for specialists whose professional activity is closely connected with family, maternity and child maintenance.

\section{Acknowledgments}

The work is performed according to the Russian Government Program of Competitive Growth of Kazan Federal University

\section{References}

Badinter, E. (1981). Mother love, Myth and reality. New York, NY: Macmillan.

Biktagirova, G. F., \& Valeeva, R. A. (2015). Formation of University Students' Readiness for Parenthood. Review of European Studies, 7(4), 93-97. http://dx.doi.org/10.5539/res.v7n4p93

Chodorow, N. (2008). The reproduction of motherhood. Los Angeles, L A: Geis.

Glenn E. N. (1994). Social constructions of mothering: A thematic overview. In E. W. Glenn, G. Chang, C. R. Forcey (Eds.), Mothering: Ideology, experience, agency (pp. 2-31). New York, NY: Plenum Press.

Goldman, W. Z. (2002). Women at the Gates Gender and Industry in Stalin's Russia. Cambridge, C: Cambridge University Press. http://dx.doi.org/10.1017/CBO9780511511868

Hay, D. F., \& Vespo, E. J. (1988). Social learning perspectives on the development of the mother-child relationship. In B. Birns, \& D. Hay (Eds.), Different faces of motherhood (pp. 156-180). New York, NY: Plenum Press. http://dx.doi.org/10.1007/978-1-4899-2109-3_4

Isupova, O. G. (2000). Motherhood and Russian Women: What it Means to Them, and their Attitudes towards It (Unpublished master's thesis). University of Manchester, Manchester, England.

Mokeyeva, E. V., Zakirova, V. G., \& Masalimova, A. R. (2015). Tolerant Pedagogic Space as a Condition of Non-Violence Position Education among Elementary School Pupils. Review of European Studies, 7(4), 216-220. http://dx.doi.org/10.5539/res.v7n4p216

Palasios, J. (2008). Parents' ideals about the development and education of their children: Answers to some questions. International Journal of Behavioral Development, 13, 137-155. http://dx.doi.org/10.1177/016502549001300201

Ramih, V. A. (1997). Motherhood as a social and cultural phenomenon (Doctoral dissertation). Rostov State University, Rostov-on-Don, Russia.

Scheide, C. (2002). Kinder, Küche, Kommunismus: Das Wechselverhältnis zwischen sowjetischem Frauenalltag und Frauenpolitik von 1921 bis 1930 am Beispiel Moskauer Arbeiterinnen. Zurich.

Shamarina, E. V. (2008). Cultural meaning of motherhood in Western European and Russian philosophical thought (Unpublished master's thesis). Altai State University, Barnaul, Russia.

Steiner, H. (2005). Die Emanzipation-A. Kollontajs in- den Widersprüchen. Berlin.

Vasyagina, N. N. (2010). Portrayals of the mother in the mental space. Proceedings of the Ural State University, 1, 105-110.

Vasyagina, N. N. (2013b). Subject Development of a Mother in Modern Socio-Cultural Environment of Russia. Ural State Pedagog Univ., Yekaterinburg.

Vasyagina, N. N. (2013a). The influence of contemporary social and cultural space of Russia on the value-semantic content of motherhood. Middle East Journal of Scientific Research, 2, 402-409.

Wood, E. (1997). The Baba and Comrade: Gender and Politics in Revolutionary Russia. Bloomington.

\section{Copyrights}

Copyright for this article is retained by the author(s), with first publication rights granted to the journal. This is an open-access article distributed under the terms and conditions of the Creative Commons Attribution license (http://creativecommons.org/licenses/by/3.0/). 